\title{
ATHYRIUM ERYTHROPODUM (WOODSIACEAE, PTERIDOPHYTA), A NEW PHILIPPINE RECORD
}

\author{
YEA-CHEN LIU ${ }^{1,2}$, CHRISTOPHER R. FRASER-JENKINS ${ }^{3}$, \\ VICTOR B. AMOROSO 4 \& WEN-LIANG CHIOU 2,5
}

\begin{abstract}
SUMMARY
Athyrium erythropodum Hayata, which was previously thought to be endemic to Taiwan, has recently been discovered in the Philippines. This species has seldom been reported or described in the literature and if so has involved erroneous morphological description and diagnosis, which has caused confusion and partly erroneous taxonomic treatment. A detailed and revised diagnostic description of the species is provided in this report, along with illustrations showing its essential features.
\end{abstract}

Key words: Athyrium erythropodum, Philippines, new record, taxonomy.

\section{INTRODUCTION}

The genus Athyrium is mainly distributed in temperate and tropical-subtropical regions of Asia. The delimitation of the genus Athyrium is not universally agreed, but modern taxonomists usually recognize Deparia (though split into several splinter-genera in mainland China), Diplazium and Cornopteris as distinct genera; the generic position of the closely related Pseudocystopteris, Anisocampium and Kuniwatsukia are still doubtful and they are generally excluded here, unless indicated otherwise. Although much further revision is still required, 117 Athyrium species have been recognized in China (Wang 1999), with the maximum species diversity of 51 species in Yunnan Province, SW China (Chu 2006) and the southeastern part of Tibet; 24 species, including one Pseudocystopteris species, are known from Taiwan (Yea-Chen Liu unpubl.); 35 species, including two Pseudocystopteris and one Anisocampium species, are known from Japan (Kato 1995); 45 species, including Pseudocystopteris, Anisocampium and Kuniwatsukia species, are known from the Indian subcontinent, excluding Sri Lanka (Fraser-Jenkins in prep. a); 8 species, including one Anisocampium species, are known from Sri Lanka (Fraser-Jenkins 2006); 16 species, including one Kuniwatsukia species, are known from Myanmar (Fraser-Jenkins in prep. b); 4 species, including one Anisocampium species, are known from Thailand (Tagawa \& Iwatsuki 1988) and only 3 species are known from Malaya (Holttum 1968). 62 species of Athyrium (including

1) Department of Biological Science, National Sun Yat-sen University, Kaohsiung, Taiwan.

2) Division of Biology, Taiwan Forestry Research Institute, Taipei, Taiwan.

3) Student Guest House, Thamel, P.O. Box 5555, Kathmandu, Nepal.

4) Department of Biology, Central Mindanao University, Musuan, Bukidnon, Philippines.

5) Corresponding author: e-mail: chiou@serv.tfri.gov.tw. 


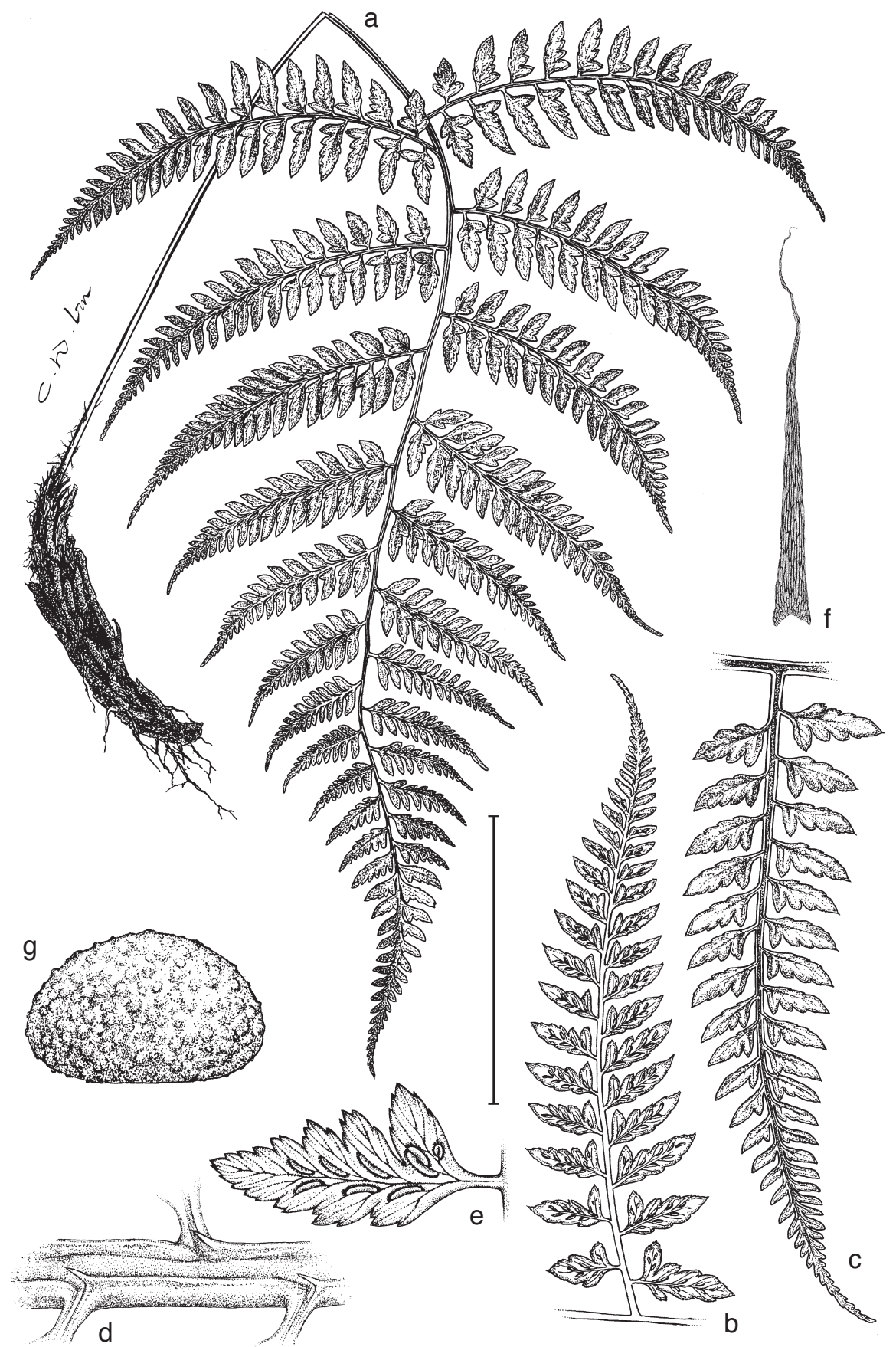

Fig. 1. Athyrium erythropodum Hayata. a. Habit; b. abaxial view of pinna; c. adaxial view of pinna; d. spines on adaxial surface of costa; e. sori; f. scale; g. spore. - Scale bars: $\mathrm{a}=10 \mathrm{~cm} ; \mathrm{b}, \mathrm{c}=5 \mathrm{~cm}$; $\mathrm{d}=2 \mathrm{~cm} ; \mathrm{e}=1 \mathrm{~cm} ; \mathrm{f}=0.5 \mathrm{~cm} ; \mathrm{g}=30 \mu \mathrm{m}$. 
Table 1. Comparative morphology of Athyrium erythropodum and allied species.

\begin{tabular}{lllll}
\hline $\begin{array}{l}\text { Morphological } \\
\text { characters }\end{array}$ & A. erythropodum & A. yakusimense & A. brevipinnulum & A. mearnsianum \\
\hline $\begin{array}{c}\text { Scales at stipe } \\
\text { base }\end{array}$ & black to glossy black & light brown & brown & black \\
$\begin{array}{c}\text { Stipe and rachis } \\
\text { indument }\end{array}$ & $\begin{array}{c}\text { glabrous, except for } \\
\text { unicellular hairs inside } \\
\text { the adaxial groove }\end{array}$ & glabrous & glabrous & pubescent \\
$\begin{array}{l}\text { Pinnule-apex } \\
\text { acute }\end{array}$ & acuminate & acute & sharply serrate & $\begin{array}{c}\text { obtuse } \\
\text { crenate to shallowly } \\
\text { sinnule-margin }\end{array}$ \\
sharply serrate & serrate & sessile & $\begin{array}{c}\text { shortly petiolate or } \\
\text { sessile }\end{array}$ \\
Pinna-petiole & $3-10 \mathrm{~mm}$ & sessile or $<2 \mathrm{~mm}$ & $\begin{array}{c}\text { sessile, partly adnate } \\
\text { to costa }\end{array}$ \\
\hline
\end{tabular}

species of Anisocampium, Cornopteris, Deparia and Diplazium) have been reported from the Philippines (Copeland 1960), but are in need of modern revision. Based on Copeland's descriptions and specimens seen in Philippine herbaria, we recognize at least 10 species of Athyrium s.s. in the Philippines, though further study of the holdings at BM, Kew and in herbaria in the United States is required.

Athyrium erythropodum Hayata (1914) was based on a collection from Mt Arisan (Alishan, Chiayi County), central Taiwan. This species occurs widely in Taiwan, growing on the semi-shaded floor of broad-leaved forests between 1500 and $2500 \mathrm{~m}$ altitude. But its identity has been confused because in the protologue (Hayata 1914) there is no mention of the costal spines present in this species. The Flora of Taiwan (DeVol \& Kuo 1975, Shieh et al. 1994) therefore stated erroneously that it was "without spines on upper surface", which caused the misplacement of this species into section Polystichoides Ching \& Y.T.Hsieh (see Wang 1997, 1999). This misunderstanding also caused the proposal of a new species, A. sungkangense C.M.Kuo, nom. nud. (Kuo 1997) based on a specimen of A. erythropodum.

Athyrium erythropodum was recently found by us on Mt Kitanglad, Mindanao Island in the Philippines, as a new country record. The first author also identified further specimens of it deposited under other names in the Philippine National Herbarium, Manila (PNH) and the Museum of Natural History Herbarium, University of the Philippines at Los Baños, Laguna (CAHUP). Here we present a comprehensive taxonomic description, distributional notes and comparison of its morphological characteristics with related species (Table 1).

\section{Athyrium erythropodum Hayata - Fig. 1}

Athyrium erythropodum Hayata (1914) 233, f. 163. Athyrium sungkangense C.M. Kuo (1997) 155, nom. nud.

Evergreen, terrestrial fern. Rhizome short erect, thick. Stipe 8-20 cm long, bearing numerous lanceolate, black or glossy black scales in its lower half; stipe and rachis purple, seldom stramineous in the living state, glabrous. Fronds bipinnate to tripinnatifid, when 
fully expanded $25-70$ by $10-60 \mathrm{~cm}$; widely deltate-lanceolate, basal pinnae opposite or subopposite, medial pairs alternate; rachis glabrous, with only a few unicellular hairs at the intersections of the adaxial surface grooves; pinnae anadromous at their base; $1.5-5$ by $5-30 \mathrm{~cm}$, ovate to broadly lanceolate, falcate, petiole $3-10 \mathrm{~mm}$ long, ascending, short spines present on the upper surface of the adaxial costae, becoming more prominent from the middle to the apex of the pinnae; lowest pinnae with elongated basiscopic pinnules; pinnules with petiole $2-3 \mathrm{~mm}$, papyraceous to chartaceous, or herbaceous; margin serrate, apex acute, becoming pinnatifid in the longer basiscopic pinnules of lower pinnae, costules of the largest pinnules sometimes bearing spines. Sor $i$ close to the midrib, linear, J-shaped or somewhat hippocrepiform, indusia persistent. Spores, perispore rugose, granulate on the surface.

Habitat - Mossy forest understory, at 1500-2500 m altitude in Taiwan, but 1900$2450 \mathrm{~m}$ in the Philippines.

Distribution - Taiwan and the Philippines (Luzon and Mindanao).

Notes - Specimens of A. erythropodum deposited in Philippine herbaria had been misidentified as A. mearnsianum and A. brevipinnulum by several taxonomists. The type of $A$. mearnsianum has the pinnules with rounded apices, crenate or shallowly serrate margins and the pinnae either sessile or with short petioles. It is thus rather easy to distinguish it from $A$. erythropodum. The other name that was misapplied is A. brevipinnulum which has brown scales on the stipe-base and sessile pinnae and pinnules. The differences of this species from A. erythropodum are given in Table 1.

According to Kuo (1985) and Shieh et al. (1994), A. erythropodum is distributed in Taiwan and South Japan. However, A. yakusimense Tagawa, from South Japan, which was listed by Kuo as a synonym of A. erythropodum, is an independent species, readily distinguishable from it by its frond morphology: pinnae sessile or less than $2 \mathrm{~mm}$ long and with light brown scales. Thus until now A. erythropodum was only known to be endemic to Taiwan. As the range of A. erythropodum is now known to extend to the Philippines it is no longer to be treated as a Taiwanese endemic.

Specimens examined:

TAIWAN. P.F. Lu 10143, 12646, 12776, 14064, B.J. Wang 14927, 17830-965, 18402, 18801-991. All specimens deposited in the Herbarium of the Taiwan Forestry Research Institute (TAIF).

PHILIPPINES. M.D. Sulit 2377 (PNH no. 5128), det. by E.B. Copeland as A. mearnsianum (Copel.) Alderw. - Mt Pauai, Luzon: M.G. Price 411 (PNH no. 113526), det. by M.G. Price as A. mearnsianum (Copel.) Alderw., M.G. Price 400 (CAHUP no. 15363), det. by M.G. Price as A. mearnsianum (Copel.) Alderw., det. by Tolentino as A. brevipinnulum Copel. - Mt Data, Luzon: Y.C. Liu 9083 (Herbarium of Central Mindanao University; TAIF), C.R. Fraser-Jenkins F.N. 73 (Herbarium of Central Mindanao University), Mt Kitanglad, Mindanao.

Specimens examined for comparison:

Athyrium mearnsianum (Copel.) Alderw.: Elmer 6543 (type of A. mearnsianum, photo in PNH), Mt Santo Tomas, Luzon, Philippines.

Athyrium brevipinnulum Copel.: M. Celestino \& A. Castro O-119 (PNH no. 3974), det. by E.B. Copeland as A. philippinense Christ, det. by M. G. Price \& J.F. Barcelona as A. brevipinnulum Copel., Mt Singakalsa, Luzon, Philippines.

\section{ACKNOWLEDGEMENTS}

The authors express their sincere thanks to the curators of the Philippine National Herbarium (PNH), Manila, the Museum of Natural History Herbarium, University of the Philippines at Los Baños 
(CAHUP), Laguna, and the Herbarium of the Taiwan Forestry Research Institute (TAIF), Taipei, for kindly allowing examination of the specimens cited. We also appreciate the help of Dr. Julie F. Barcelona $(\mathrm{PNH})$ for kindly providing type specimen pictures. Thanks are also given to Mr. Lin, Che-wei, of TAIF, Taipei, for the drawings and illustrations accompanying this paper.

\section{REFERENCES}

Chu, W.M. 2006. Athyriaceae. In: W.M. Chu (ed.), Flora Yunnanica 20: 357-558. Science Press, Beijing, China.

Copeland, E. B. 1960. Athyrium. In: E. B. Copeland, Fern flora of the Philippines 3:379-418. National Institute of Science \& Technology, Manila.

DeVol, C.E. \& C.M. Kuo. 1975. Athyriaceae. In: H.L. Li et al. (eds.), Flora of Taiwan, ed. 1, 1: 441-475. Epoch Publishing, Taipei, Taiwan.

Fraser-Jenkins, C.R. 2006. Woodsiaceae. In: M. Shaffer-Fehre (ed.), Flora of Ceylon 15B. Ferns and fern allies: 532-576. Science Publishers. Enfield, NH, USA.

Fraser-Jenkins, C.R. In prep. a. Himalayan athyrioid ferns.

Fraser-Jenkins, C.R. In prep. b. Pteridophytes of Myanmar - a revised annotated check-list.

Hayata, B. 1914. Icones plantarum formosanarum 4. Taihoku: Bureau of Productive Industries, Taihoku, Taiwan.

Holttum, R.E. 1968. A revised flora of Malaya 2. Ferns of Malaya, ed. 2. Singapore Government Printing Office.

Kato, M. 1995. Woodsiaceae. In: K. Iwatsuki, T. Yamazaki, D.E. Boufford \& H. Ohba (eds.), Flora of Japan 1: 195-231. Kodansha, Tokyo.

Kuo, C.M. 1985. Taxonomy and phytogeography of Taiwanese pteridophytes. Taiwania 30: 5-100.

Kuo, C.M. 1997. Manual of Taiwan vascular plants 1: 155. Council of Agriculture, Taipei, Taiwan. (In Chinese.)

Shieh, W.C., C.E. DeVol \& C.M. Kuo. 1994. Athyriaceae. In: T.C. Huang et al. (eds.), Flora of Taiwan, ed. 2, 1: 414-448. Editorial Committee, Department of Botany, National Taiwan University, Taipei, Taiwan.

Tagawa, M. \& K. Iwatsuki. 1988. Flora of Thailand 3, 3. Chutima Press, Bangkok, Thailand.

Wang, Z.R. 1997. A revision of the Chinese Athyrium Roth (I) - subgeneric classification of the genus. Bulletin of Botanical Research 17: 274-300.

Wang, Z.R. 1999. Athyrium. In: W.-M. Chu (ed.), Flora Reipublicae Popularis Sinicae 3: 98-267. Science Press, Beijing, China. (In Chinese.) 